\title{
Growth and abundance of Synechococcus sp. in a Mediterranean Bay: seasonality and relationship with temperature
}

\author{
Nona S. R. Agawin*, Carlos M. Duarte, Susana Agustí \\ Centro de Estudios Avanzados de Blanes, CSIC, Camino de Santa Bàrbara s/n, E-17300 Blanes (Girona), Spain
}

\begin{abstract}
In this study, we confirm the relationship between temperature and Synechococcus $\mathrm{sp}$ experimental growth rates $(r=0.87, p<0.005)$ and provide evidence of the existence of a general relationship. This link leads to a strong seasonality of abundance and biomass of Synechococcus sp. in the Bay of Blanes (NW Mediterranean), which was followed for 2 yr $(1995,1996)$, with high values in summer months $\left(6 \times 10^{7}\right.$ cells $\left.\mathrm{l}^{-1}\right)$ and low values in winter $\left(5 \times 10^{5}\right.$ cells $\left.\mathrm{l}^{-1}\right)$. The growth rate achieved in summer months $\left(1.5 \mathrm{~d}^{-1}\right)$ is close to or at the maximum possible at the in situ water temperature. As a result, Synechococcus growth may exceed the grazing capacity of its predators in summer, and this explains its significant contribution of $>30 \%$ of the total gross autotrophic production and $>20 \%$ of the total autotrophic biomass in summer Thus, Synechococcus is an important source of organic $\mathrm{C}$ and nutrients for the coastal Mediterranean food web in the summer.
\end{abstract}

KEY WORDS: Synechococcus sp. - NW Mediterranean Sea Growth and abundance - Temperature

\section{INTRODUCTION}

Picocyanobacteria (Synechococcus sp.) are important contributors to primary production in the ocean, particularly in warm, nutrient-poor waters (Stockner \& Antia 1986, Stockner 1988). This suggests that the contribution of cyanobacteria in temperate seas should be most important in the summer, when water temperature is highest and the seasonal thermocline limits the supply of nutrients to the upper layer. Although Synechococcus growth rate is expected to be higher in the summer, its abundance may not show a similar trend, because Synechococcus is heavily grazed by protists (Kuosa 1991, Mura et al. 1996b, Agawin \& Agustí 1997). These grazers may effectively remove the entire daily production of Synechococcus (Agawin \& Agustí 1997), thereby maintaining a uniform abundance. The hypothesis that Synechococcus growth and abundance should be higher in summer requires the investigation of the seasonality. Unfortunately, coherent investiga-

•E-mail: agawin@ceab.csic.es tions of the seasonality in the abundance and growth of Synechococcus in temperate waters are scarce, although available information suggests that its abundance is closely related to annual cycles of water temperature, having the maximum values in mid summer (Krempin \& Sullivan 1981, Waterbury et al. 1986, Modigh et al. 1996). In addition, available information also suggests a temperature-dependence of production rates and of the relative contribution of Synechococcus to total phytoplankton biomass (i.e. high values in summer) in temperate waters (Joint 1986, Modigh et al. 1996).

Here we examine the seasonality in the abundance and growth rate of Synechococcus sp. in the Bay of Blanes (NE Spain) to test the hypothesized correlation between temperature and growth rate. We then test whether changes in growth rate result in differences in abundance and the relative contribution of Synechococcus to planktonic autotrophic biomass. This Mediterranean Bay is particularly well suited for this test because its waters experience a broad temperature range $\left(11\right.$ to $\left.26^{\circ} \mathrm{C}\right)$ throughout the year, being warm and nutrient-poor in the summer and cold and 
nutrient-enriched in winter (Cebrián et al. 1996). Available information suggests that Synechococcus reaches maximum abundance in the summer in Blanes Bay (Mura et al. 1996a), indicating that it can contribute significantly to total phytoplankton production. However, protist grazers appear to be able to remove most of its production (Mura et al. 1996b).

\section{METHODS}

The study was conducted in the Bay of Blanes, NW Mediterranean Sea $\left(41^{\circ} 39.90^{\prime} \mathrm{N}, 2^{\circ} 48.03^{\prime} \mathrm{E}\right)$ from January 1995 to January 1997 . The shallow waters of the Bay of Blanes are vertically mixed and receive little freshwater input during most of the year, except for irregular freshwater pulses during storms (Cebrián et al. 1996). Salinity ranges between 37 and $38 \%$ and is remarkably uniform over the year, except when oceanic water intrusion or pulses of freshwater discharge occur. Temperature ranges from $11^{\circ} \mathrm{C}$ (late January to March) to $26^{\circ} \mathrm{C}$ (August to September) (cf. Cebrián et al. 1996). Phosphate and nitrate levels are generally low in summer (concentrations below 0.15 and $0.3 \mu \mathrm{M}$, respectively), and phytoplankton net community production is low throughout the year except during blooms occurring in late winter when net community production reaches $0.02 \mathrm{mg} \mathrm{O}_{2} \mathrm{I}^{-1} \mathrm{~h}^{-1}$ (Satta et al. 1996). Phytoplankton biomass in Blanes Bay reaches maximum values in February to March (late winter bloom) when the community is dominated by centric diatoms (Mura et al. 1996a).

Sampling was conducted at weekly intervals from subsurface waters $(0.5$ to $1 \mathrm{~m})$ at a fixed coastal station (of about $20 \mathrm{~m}$ deep). Weekly samples were collected in the morning (from 08:00 to 14:00 h) and each time the temperature of the water sampled $\left( \pm 0.1^{\circ} \mathrm{C}\right)$ was immediately recorded with a thermometer. A volume of seawater was collected by grab sampling and $250 \mathrm{ml}$ was preserved with glutaraldehyde (to $1 \%$ final concentration) for microscopic examination of phytoplankton. From this volume, a subsample of $25 \mathrm{ml}$ (in summer months when abundance is high.) to $60 \mathrm{ml}$ (in winter months when abundance is low) was filtered at low pressure ( 1 to $2 \mathrm{~cm} \mathrm{Hg}$ ) through $0.20 \mu \mathrm{m}$ black Nuclepore filters for enumeration of cyanobacteria. The filter was then mounted on a glass slide over a drop of Zeiss immersion oil and kept frozen until examination under epifluorescence microscopy. Cyanobacteria of the phycoerythrin-rich genus Synechococcus emit a yellow-orange fluorescence when excited with light at 560 to $570 \mathrm{~nm}$ (blue region). The number of Synechococcus was counted in 10 to 20 randomly chosen microscope fields of $100 \times 100 \mu \mathrm{m}$ size (at $1000 \times$ magnification) using a Zeiss Axioplan epifluo- rescence microscope (average of 230 cells per filter counted). Cells in division, those having a complete cross wall between them, were also counted. The frequency of cells in division (FDC) was determined by dividing the number of cells undergoing division by the total number of cells counted. Cell sizes of between 20 and 30 cells per filter were also measured using a video camera attached to the microscope, with a calibrated TV screen $(0.2 \mu \mathrm{m}=1 \mathrm{~mm}$ on the TV screen), and cell volume was computed by approximation based on the coccoid shape of Synechococcus cells. Synechococcus biovolume was calculated as the product of abundance or cell density and average cell volume.

Growth experiments were conducted throughout the second year of the study, starting in February 1996 when the temperature was $13^{\circ} \mathrm{C}$ and repeated as sea surface temperature changed by approximately $2^{\circ} \mathrm{C}$. The experiments ended in January 1997 when temperature was lowest at $11^{\circ} \mathrm{C}$. Growth experiments were conducted in duplicate according to the procedure described by Agawin \& Agustí (1997), modified from that of Affronti \& Marshall (1994). For each growth experiment, a 6 l surface water sample was collected by grab sampling and half of it was filtered through Whatman GF/F filters. The natural seawater sample was diluted with the filtered seawater to reduce grazing pressure and nutrient limitation during the incubation (Affronti \& Marshall 1994). The mixture was dispensed into two 41 glass jars and incubated in a chamber set at $100 \mu \mathrm{E} \mathrm{m}^{-2} \mathrm{~s}^{-1}$, sufficient to saturate growth (Morris \& Glover 1981, Barlow \& Alberte 1985, Moore et al. 1995), with the photoperiod and temperature adjusted to those in the Bay. A subsample of between 25 and $80 \mathrm{ml}$ was taken from each duplicated incubation jar and fixed immediately with glutaraldehyde ( $1 \%$ final concentration) every $2 \mathrm{~h}$ for $24 \mathrm{~h}$. Filtration, determination of abundance and frequency of dividing cells were done as described above. Growth rates were calculated from the slope of the regression of the natural logarithm of abundance versus time during the growth phase, where the growth phase was determined graphically as the period of increase in cell numbers (Agawin \& Agustí 1997). Growth rates in units $\mathrm{h}^{-1}$ were translated to units $\mathrm{d}^{-1}$ by multiplying them by the duration of the growth period, which averaged $5.6 \mathrm{~h}$ (range: 3 to $10 \mathrm{~h}$ ), as determined empirically over the $24 \mathrm{~h}$ experiments.

Parametric correlation and regression analyses between parameters (abundance, FDC, growth and temperature) were done when the data followed bivariate normal distribution (tested using the KolmogorovSmirnov test; Sokal \& RohIf 1981), otherwise a nonparametric Spearman correlation was used. 
Gross and net production rates and loss rates of Synechococcus at time $t$ were calculated as

$$
\begin{gathered}
P_{\text {gross }}\left(\text { in } \mu \mathrm{gC}^{-1} \mathrm{~d}^{-1}\right)=\left(\text { Biomass }_{t} \times \mathrm{e}^{g}{ }_{t}\right)-\text { Biomass }_{t} \\
P_{\text {net }}=\frac{\left(\text { Biomass }_{t}-\text { Biomass }_{t-1}\right)}{\text { Time between samples }}
\end{gathered}
$$

where Biomass ${ }_{t-1}=$ biomass in $\mu \mathrm{gCl}^{-1}$ in the previous sampling, Biomass $t=$ biomass in $\mu \mathrm{g} \mathrm{Cl}^{-1}$ at time $t$, and $g=$ growth rate of Synechococcus at time $t$ interpolated from the linear regression equation between in situ temperature and experimental growth rates.

$$
\text { Loss rate (in } \left.\mu \mathrm{g} \mathrm{Cl}^{-1} \mathrm{~d}^{-1}\right)=P_{\text {gross }}-P_{\text {net }}
$$

The biovolume and production of Synechococcus were compared to the total biovolume and gross production of the autotrophic community in Blanes Bay, determined on a parallel sampling programme (for the method of biovolume determination of phytoplankton other than Synechococcus, and determination of gross production, see Mura et al. 1996a and Satta et al. 1996, respectively). The Synechococcus production in biovolume was transformed to $\mathrm{C}$-based production assuming a carbon content of $0.123 \mathrm{pg} \mathrm{C} \mu \mathrm{m}^{-3}$ (Waterbury et al. 1986), and the gross production of the whole autotrophic community, based on $\mathrm{O}_{2}$ evolution rates, was transformed to $\mathrm{C}$ using a photosynthetic quotient of 1.2

\section{RESULTS AND DISCUSSION}

The abundance of Synechococcus in the Bay of Blanes showed a clear seasonal pattern, with minimum abundance during winter (about $5 \times 10^{5}$ cells $\mathrm{I}^{-1}$ ), increasing in spring, and peaking during summer $(7 \times$ $10^{7}$ and $5 \times 10^{7}$ cells $l^{-1}$ in 1995 and 1996 , respectively; Fig. 1A). Synechococcus cells tended to be larger in winter (1995) and smaller during the 2 summers (1995 and 1996; Fig. 1B), but the biovolume of Synechococcus followed the same seasonal pattern described for their abundance (Fig. 1C).

The distinct seasonal pattern of Synechococcus abundance may be a consequence of changes in population growth rates since the frequency of cells in division (FDC) tended to have peak values in late spring, preceding the occurrence of peak abundances of cells in summer (Fig. 1D). In most of our growth incubation experiments, FDC of Synechococcus followed the same diel periodicity of maximum FDC in the morning (from 08:00 to 14:00 h). The weekly samples were taken during this period, which suggests that the variability of FDC observed with time reflects a general seasonal pattern and was not influenced by variability of sampling and diel periodicity. The FDC ranged from virtually zero in winter to $20 \%$ of the population in late spring, and was well correlated with cell abundance ( $r=0.64$, Spearman correlation). This indicates that the temporal variation of abundance reflects variation in gross growth rates, which should be associated to differences in the FDC (McDuff \& Chisholm 1982). Both abundance and the FDC of Synechococcus cells increased as the waters warmed up $(\mathrm{r}=0.76$ and $\mathrm{r}=0.42$, respectively, Spearman correlation; Fig. 1A, D), suggesting that the observed seasonality may reflect a strong correlation between Synechococcus growth rate and in situ temperature.

Growth rates differed greatly along the year, being highest $\left(1.5 \mathrm{~d}^{-1}\right)$ in summer and lowest $\left(0.2 \mathrm{~d}^{-1}\right)$ in winter (Fig. 2A). There was, as suggested by the examination of the FDC, a strong, positive relationship between growth rate and temperature $(\mathrm{r}=0.87, \mathrm{p}<0.005$; Fig. 2B), which accounted for $88 \%$ of the variance in growth rate observed along the year. The relationship was best described by the regression equation:

$$
\begin{aligned}
\text { Growth rate }\left(\mathrm{d}^{-1}\right)= & 0.094( \pm 0.014) \times \operatorname{Temp}\left({ }^{\circ} \mathrm{C}\right) \\
& -0.762( \pm 0.244)
\end{aligned}
$$

The strong seasonality in the growth and abundance of Synechococcus reported here was reflected in the variation of the relative contribution of Synechococcus to total phytoplankton biovolume. Synechococcus contributed only $0.6 \%$ of the autotrophic biovolume in winter, when it was least abundant and when total phytoplankton biomass was relatively high, and comprised $>20 \%$ of the autotrophic biovolume in summer (Fig. 3A), when it was most abundant and autotrophic biomass was relatively low. Together with small autotrophic phytoplankton (mostly small flagellates) between 2 and $5 \mu \mathrm{m}$, Synechococcus dominates the phytoplankton communities in summer. Hence, there is a seasonal shift from communities dominated by diatoms (Chaetoceros, Thalassiosira, Nitzschia) in winter (Mura et al. 1996a) to communities dominated by smaller autotrophs in summer.

The decline of biomass of the larger phytoplankton from high values in winter to low values in summer may be due to increased grazing pressure (Mura et al 1996b) as the biomass of zooplankton consumers (e.g. copepod nauplii and cnidaria) is greatest in summer (Andreu \& Duarte 1996). Alternatively, it could be associated to nutrient limitation derived from the depletion of dissolved inorganic nutrients in summer. The observed importance of Synechococcus in summer, when the concentration of nutrients is lowest, supports the suggestion that by virtue of their small size they are more efficient in nutrient acquisition in oligotrophic environments than larger cells (Raven 1986). 

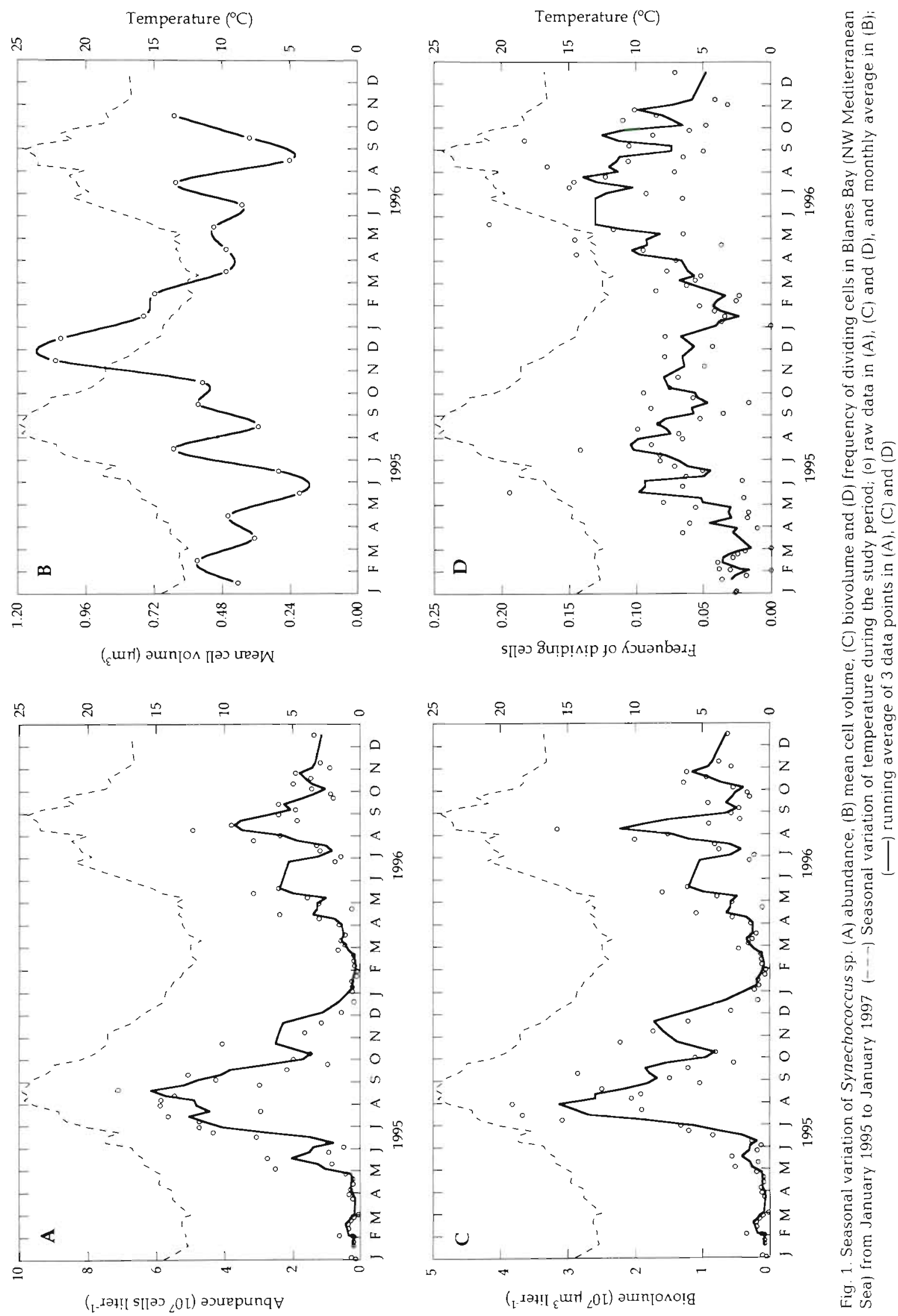

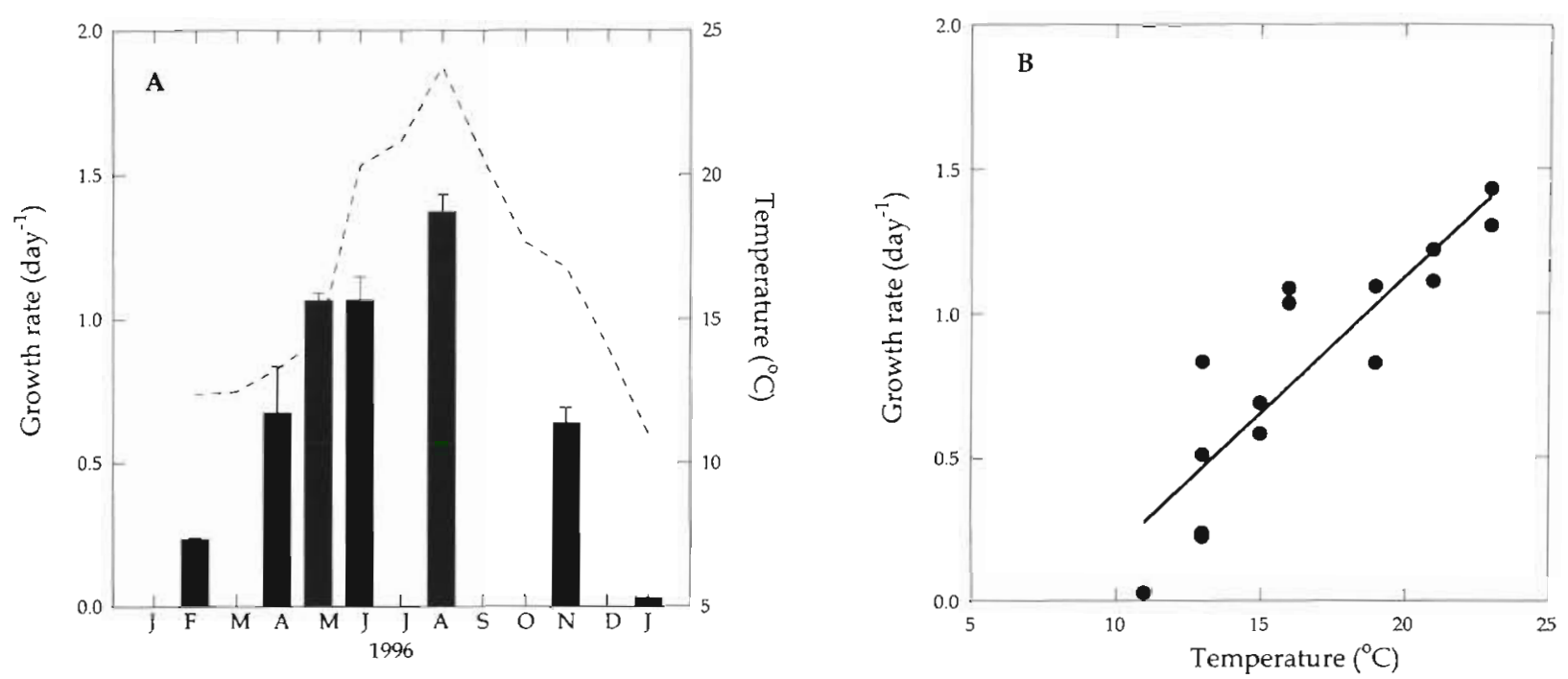

Fig. 2. (A) Variability of Synechococcus sp. growth rates in Blanes Bay from the growth experiments conducted from February 1996 to January 1997. (--) In situ surface temperature during the period of study. (B) Relationship between Synechococcus sp. growth rates in Blanes Bay and sea surface water temperature. (-) Fitted regression equation

The close relationship between picocyanobacterial (Synechococcus) growth rate and temperature observed in Blanes Bay may differ for other species and systems. We tested the generality of the relationship between Synechococcus growth rate and temperature by searching the literature for field data on picocyanobacteria, mostly Synechococcus, growth from cold temperate oceans to tropical ones (Fig. 4). The reports obtained encompassed a wide temperature range from $-0.5^{\circ} \mathrm{C}$ encountered in Long Island Sound, USA (Carpenter \& Campbell 1988) to $25^{\circ} \mathrm{C}$ in the North Pacific Ocean (Iturriaga \& Mitchell 1986) and growth rates ranging from 0 to $2.3 \mathrm{~d}^{-1}$. We have also included data from laboratory studies using different strains of Synechococcus sp. in the range of temperature en.

Fig. 3. Seasonal variation of percent Synechococcus sp. contribution to (A) total phytoplankton biovolume in Blanes Bay from January 1995 to December 1996 and (B) total phytoplankton production (derived from $\mathrm{O}_{2}$ evolution rates) in Blanes Bay from January 1995 to November 1996 . The $\mathrm{O}_{2}$-based gross production was transtormed to $C$ using a photosynthetic quotient of 1.2 . Bars represent standard error for each month
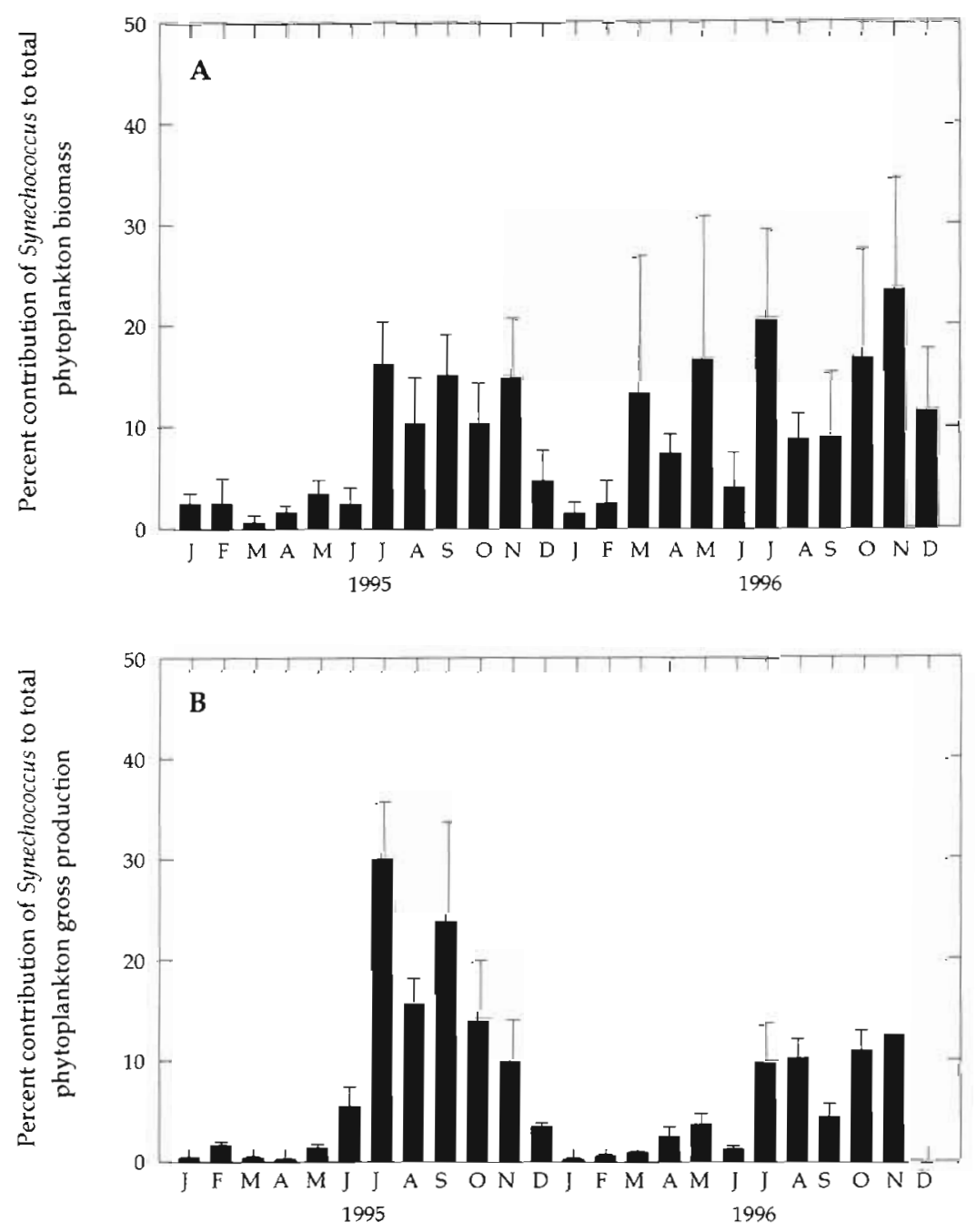


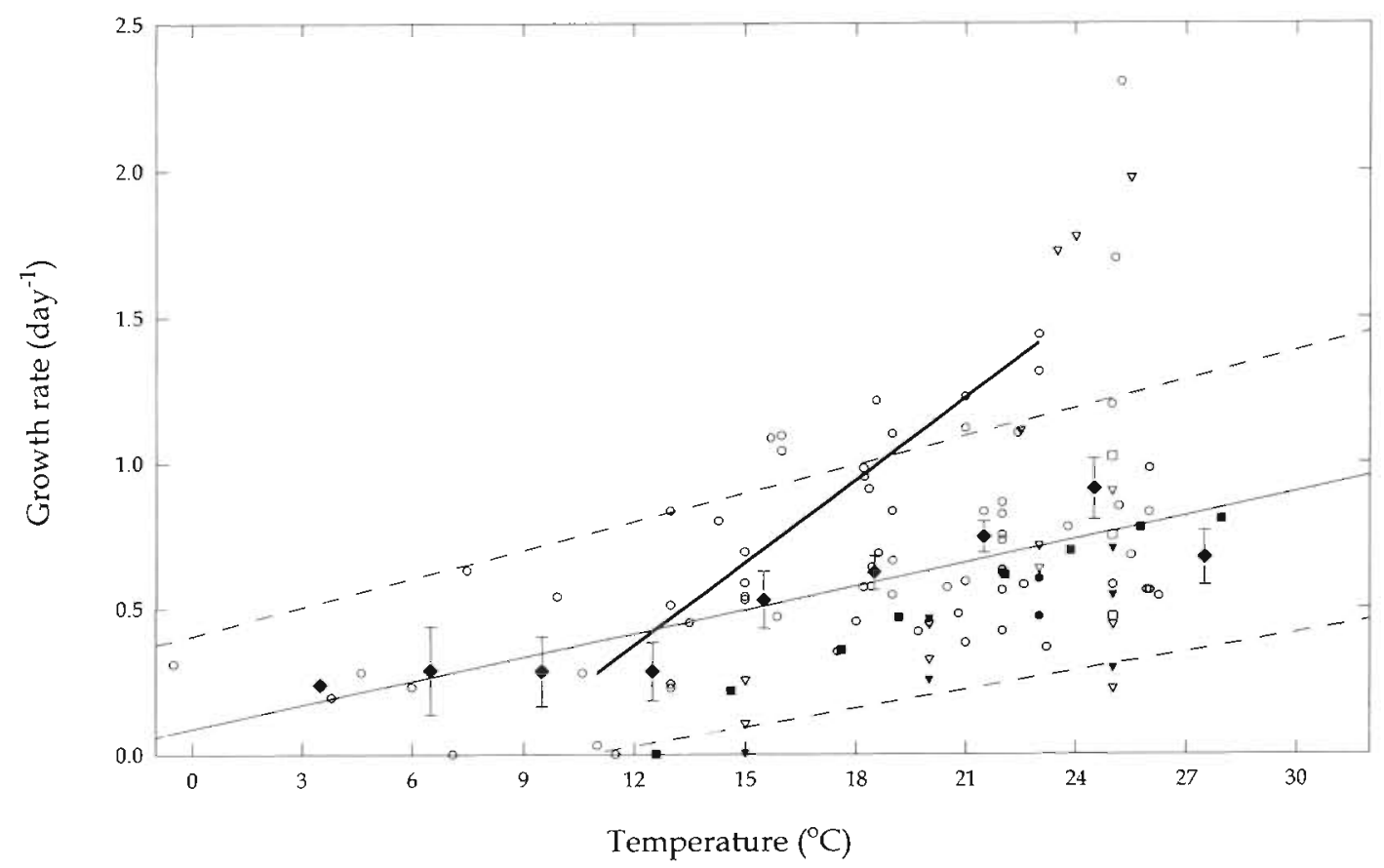

Fig. 4. Variation of autotrophic marine picoplankton (mostly Synechococcus sp.) growth rates with temperature from a literature survey (and the method used to estimate growth). (o) Individual data points from field studies: Bienfang \& Takahashi (1983; size fractionation, biomass change with time), Campbell \& Carpenter (1986; FDC technique), Iturriaga \& Mitchell (1986; size fractionated photosynthesis), Prézelin et al. (1987; FDC technique), Carpenter \& Campbell (1988; FDC technique), Iturriaga \& Marra (1988; size fractionated photosynthesis). Affronti \& Marshall (1994; dilution, population change with time), Agawin \& Agustí (1997; dilution, population change with time). Different symbols represent data from culture studies using different strains of Synechococcus: (ㅁ) WH 8012 (Campbell \& Carpenter 1986), (•) WH 8103 (Moore et al. 1995), ( $)$ WH 8107 (Campbell \& Carpen-

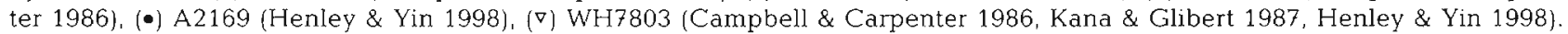
(•) Mean growth rates within $3^{\circ} \mathrm{C}$ bins and their standard error. Thin solid and dashed lines represent the regression line and $95 \%$ confidence limits through the mean values, respectively. Bold solid line represents the regression between growth rate and temperature in the Bay of Blanes

countered in the field. The analysis of these data supported the existence of a significant correlation between seawater temperature and picocyanobacteria growth ( $\mathrm{r}=0.46, \mathrm{p}<0.00001$; Fig. 4). The expected growth rate of picocyanobacteria at a particular temperature was described by regressing the mean growth rate within $3^{\circ} \mathrm{C}$ bins against the mean temperature. The regression equation obtained:

$$
\text { Growth rate } \begin{aligned}
\left(\mathrm{d}^{-1}\right) & =0.0270( \pm 0.005) \times \text { Temp }\left({ }^{\circ} \mathrm{C}\right) \\
& +0.088(0.082) \\
(\mathrm{r} & =0.91, \mathrm{p}<0.001)
\end{aligned}
$$

indicates a rate of change in picocyanobacteria growth with increasing temperature somewhat lower than that obtained in Blanes Bay $10.0270 \pm 0.005$ vs $0.094 \pm 0.014$, t-test, $p<0.05$;. Synechococcus growth rate in Blanes Bay is near the average potential rate of that predicted by Eq. (2) from in situ temperature during winter (at the lowest range of temperature) and is near the upper $95 \%$ confidence limit of the predicted growth rate during summer (Fig. 4). This observation suggests that in winter, Synechococcus growth is at its average poten- tial rate, while Synechococcus grows at a near maximal rate (i.e. close to the upper $95 \%$ c.l. of the predicted growth rate from temperature) in summer in the Bay, when temperature and irradiance are high and nutrient concentrations are low. Whatever the physiological basis of the correlation between cyanobacterial growth and temperature, strains of freshwater Synechococcus have been reported to achieve optimal growth at a temperature of about $53^{\circ} \mathrm{C}$, reaching maximum growth rates of $6.9 \mathrm{~d}^{-1}$ (Philips \& Mitsui 1982). The observation that maximum growth is reached at such high temperatures is consistent with the linear increase in growth of marine Synechoccocus with increasing temperature, observed in nature.

The gross production (and subsequent calculation of losses) estimated here, based on the growth rates of $50 \%$ dilution experiments, could be underestimated because, at $50 \%$ dilution, grazer activity may not be significantly reduced. However, the estimated gross growth rates were within the growth rates found in the literature (Fig. 4). Moreover, during summer, the growth rates found were close to the maximal growth 
rates found in the literature (Fig. 4) and the gross production values of Synechococcus in the Bay of Blanes were within the range of those reported for oligotrophic environments (Stockner \& Antia 1986, Magazzù \& Decembrini 1995), giving us confidence in our estimates. Gross production showed a seasonal trend from very low values in winter $\left(0.01 \mu \mathrm{g} \mathrm{C}^{-1} \mathrm{~d}^{-1}\right)$ to relatively high values in summer $\left(16 \mu \mathrm{g} \mathrm{C} \mathrm{l^{-1 }} \mathrm{d}^{-1}\right.$; Fig. 5A). The comparison of Synechococcus production with concurrent estimates of gross production of the autotrophic community (from $\mathrm{O}_{2}$ evolution; Agustí unpubl. data) showed that Synechococcus contributed a major percentage of the summer production (Fig. 3B) even when considering that the production estimates derived for Synechococcus underestimate their gross production, since the $\mathrm{C}$ respired or exudated is not included here, but is included in the $\mathrm{O}_{2}$-based community gross production. The production of Synechococcus appears to be completely removed by loss processes during winter but is not completely consumed during summer, resulting in a sizeable maximum net production of up to $0.3 \mu \mathrm{g} \mathrm{Cl}^{-1} \mathrm{~d}^{-1}$ (Fig. 5A, $B)$. However, net production drastically declines in autumn (after the summer peak), suggesting heavy grazing by protists during this period. The calculated loss rates reach $5.0 \mathrm{~d}^{-1}$, exceeding published estimates of the loss rates of $\mathrm{mi}$ crophytoplankton (Mura et al, 1996b) and bacteria (del Giorgio et al. 1996) in this Bay, but consistent with the observation that losses are very high in the Bay of Blanes (Mura et al. 1996b). The losses of Synechococcus in the open NW Mediterranean have been found to be largely attributable to grazing (Agawin \& Agustí 1997). Losses were, however, insufficient to remove all of the high $C$ production in summer, allowing the proliferation of the Synechococcus population in summer. Losses and growth were, however, in a quasi perfect balance $(r=0.99)$ when averaged over a few weeks (Fig. 5A), so that although coupling between losses and gains may be weak at short ( $1 \mathrm{wk}$ ) time intervals, it is very strong at monthly intervals. This is in agreement with the strong top-down control experienced by microphytoplankton communities (Mura et al. 1996a) and bacterioplankton (del Giorgio et al. 1996) in the Bay of Blanes.
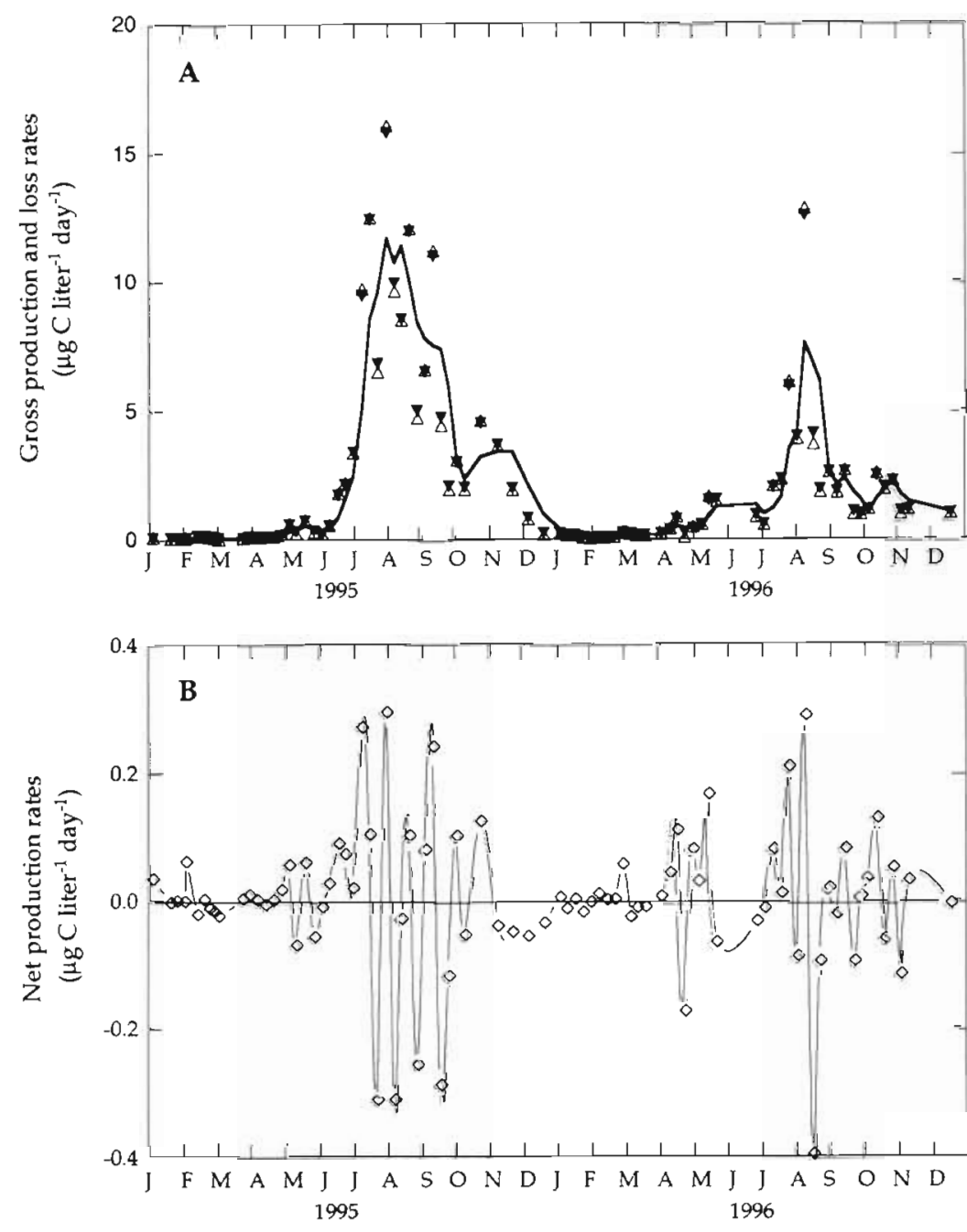

Fig. 5. Seasonal variation of (A) gross production ( $\Delta$ ) and loss rates ( $\nabla$ ), and (B) net production of Synechococcus sp. in the Blanes Bay from January 1995 to December 1996. Lines in (A) represent running averages of 3 data points (for gross production and loss rates, the lines are not distinguishable from each other), while lines in (B) go through individual data points. The production in biovolume was transformed to C-based production using a conversion factor of $0.123 \mathrm{pg} \mu \mathrm{m}^{-3}$ (Waterbury et al. 1986)

The significant contribution of Synechococcus to total phytoplankton biomass and production during summer in the studied coastal Mediterranean system indicates that they are an important source of organic $C$ and nutrients to the planktonic food web. Heterotrophic flagellates (Johnson et al. 1982) have been reported to directly utilize and assimilate Synechococcus, and thus transfer picocyanobacteria to nano-sized (2 to $20 \mu \mathrm{m}$ ) plankton (Stockner \& Antia 1986). Synechococcus is suggested to be an important carbon source for heterotrophic nanoflagellates in the Bay of Blanes, as evidenced by a positive significant relationship between Synechococcus and heterotrophic nanoflagellate abundance (Vazquez et al. unpubl.). Our results sug- 
gest, therefore, that Synechococcus is an important component of the planktonic food web in summer.

In summary, the results presented confirm the existence of a general positive relationship between temperature and Synechococcus sp. growth rate. This link leads to a strong seasonality of abundance and biomass of Synechococcus sp. in the NW Mediterranean littoral, with high values in summer months and low values in winter. The growth rate achieved in summer months is close to or at the maximum possible at the in situ water temperature. As a result, Synechococcus growth exceeds the grazing capacity of its predators over short periods of time in summer, and results in its significant contribution to total autotrophic biomass and production. Hence, Synechococcus is suggested to be an important autochthonous source of organic $C$ and nutrients for the coastal Mediterranean food web in summer.

Acknowledgements. This study was funded by the European Commission under the MAST programme (contract MAS3CT96-0045) and by the Spanish Commission of Science and Technology (CICYT project AMB94-0746). N.S.R.A. is supported by a fellowship of the Agencia Espanola de Cooperación Intemacional. We thank $\mathrm{C}$. Chiscano, M. Sarmiento for assistance in counting the samples and G. Carreras, E. Benavent and J. Terrados for help and D. Bird for usetul comments on the manuscript.

\section{LITERATURE CITED}

Affronti LF, Marshall HG (1994) Using frequency of dividing cells in estimating autotrophic picoplankton growth and productivity in the Chesapeake Bay. Hydrobiologia 284: $193-203$

Agawin NSR, Agustí S (1997) Abundance, frequency of dividing cells and growth rates Synechococcus sp. (Cyanobacteria) in the stratified Northwest Mediterranean Sea. J Plankton Res 19:1599-1615

Andreu P, Duarte CM (1996) Zooplankton seasonality in Blanes Bay (northwest Mediterranean). In: Duarte CM (ed) Seasonality in Blanes Bay: a paradigm of the NW Mediterranean littoral. Publ Espec Inst Esp Oceanogr 22: $47-54$

Barlow RG, Alberte RS (1985) Photosynthetic characteristics of phycoerythrin-containing marine Synechococcus spp. I. Responses to growth flux density. Mar Biol 86:63-74

Bienfang PK, Takahashi M (1983) Ultraplankton growth rates in a subtropical ecosystem. Mar Biol 76:213-218

Campbell EJ, Carpenter L (1986) Diel patterns of cell division in marine Synechococcus spp. (Cyanobacteria): use of the frequency of dividing cells technique to measure growth rate. Mar Ecol Prog Ser 32:139-148

Carpenter EJ, Campbell L (1988) Diel patterns of cell division and growth rates of Synechococcus spp. in Long Island Sound. Mar Ecol Prog Ser 47:179-183

Cebrián J, Duarte CM, Pascual J (1996) Marine climate on the Costa Brava (northwest Mediterranean) littoral. In: Duarte CM (ed) Seasonality in Blanes Bay: a paradigm of the NW Mediterranean littoral. Publ Espec Inst Esp Oceanogr 22 9-21 del Giorgio PA, Gasol JM, Vaqué D, Mura P, Agustí S, Duarte CM (1996) Bacterioplankton community structure: protists control net production and the proportion of active bacteria in a coastal marine community. Limnol Oceanogr 41: $1179-1179$

Henley WJ, Yin Y (1998) Growth and photosynthesis of marine Synechococcus (Cyanophyceae) under iron stress. J Phycol 34:94-103

Iturriaga R, Marra J (1988) Temporal and spatial variability of chroococcoid cyanobacteria Synechococcus spp. specific growth rates and their contribution to primary production in the Sargasso Sea. Mar Ecol Prog Ser 44:175-181

Iturriaga R, Mitchell BG (1986) Chroococcoid cyanobacteria: a significant component in the food web dynamics of the open ocean. Mar Ecol Prog Ser 28:291-297

Johnson PW, Xu HS, Sieburth JMcN (1982) The utilization of chroococcoid cyanobacteria by marine protozooplankters but not by calanoid copepods. Ann Inst Oceanogr Paris 58: $297-308$

Joint IR, Owens NPJ, Pomroy AJ (1986) The seasonal production of picoplankton and nanoplankton in the Celtic Sea. Mar Ecol Prog Ser 28:251-258

Kana TM, Glibert P (1987) Effect of irradiances up to $2000 \mu \mathrm{E}$ $\mathrm{m}^{-2} \mathrm{~s}^{-1}$ on marine Synechococcus WH 7803-II. Photosynthetic responses and mechanisms. Deep-Sea Res 34(4): $497-516$

Krempin DW, Sullivan CW (1981) The seasonal abundance, vertical distribution, and relative microbial biomass of chroococcoid cyanobacteria at a station in southern California coastal waters. Can J Microbiol 27:1341-1344

Kuosa H (1991) Picoplanktonic algae in the northern Baltic Sea: seasonal dynamics and flagellate grazing. Mar Ecol Prog Ser 73:269-276

Magazzù G, Decembrini F (1995) Primary production, biomass and abundance of phototrophic picoplankton in the Mediterranean Sea: a review. Aquat Microb Ecol 9: $97-105$

McDuff RE, Chisholm SW (1982) The calculation of in situ growth rates of phytoplankton populations from fractions of cells undergoing mitosis: a clarification. Limnol Oceanogr 27:783-788

Modigh M, Saggiomo V, Ribera d'Alcalà M (1996) Conservative features of picoplankton in a Mediterranean eutrophic area, the Bay of Naples. J Plankton Res 18(1):87-95

Moore LR, Goericke R, Chisholm SW (1995) Comparative physiology of Synechococcus and Prochlorococcus: influence of light and temperature on growth, pigments, fluorescence and absorptive properties. Mar Ecol Prog Ser $116: 259-275$

Morris I, Glover HE (1981) Physiology of photosynthesis by marine coccoid cyanobacteria-some ecological implications. Lumnol Oceanogr 26:957-961

Mura MP, Agustí S, Cebrián J, MP Satta (1996a) Seasonal variability of phytoplankton biomass and community composition in Blanes Bay (1992-1994). In: Duarte CM (ed) Seasonality in Blanes Bay: a paradigm of the NW Mediterranean littoral. Publ Espec Inst Esp Oceanogr 22:23-29

Mura MP, Agustí S, del Giorgio PA, Gasol JM, Vaqué D, Duarte C (1996b) Loss-controlled phytoplankton production in nutrient-poor littoral waters of the NW Mediterranean: in situ experimental evidence. Mar Ecol Prog Ser 130:213-219

Philips EJ, Mitsui A (1982) Temperature preference and tolerance of aquatic photosynthetic microorganisms. In: Mitsui A, Black CC (eds) CRC handbook of biosolar resources, Vol 1, Basic principles, Part 2. CRC Press Inc, Boca Raton, FL, p 335-361 
Prézelin BB, Glover HE, Campbell L (1987) Effects of light intensity and nutrient availability on diel patterns of cell metabolism and growth in populations of Synechococcus spp. Mar Biol 95:469-480

Raven JA (1986) Physiological consequences of extremely small size for autotrophic organisms in the sea. In: Platt T, Li WKW (eds) Photosynthetic picoplankton. Can Bull Fish Aquat Sci 214:1-70

Satta MP, Agustí S, Mura MP, Duarte CM (1996) Seasonal variability of planktonic gross primary production off Blanes Bay (March 1992-March 1994). In: Duarte CM (ed) Seasonality in Blanes Bay: a paradigm of the NW Mediterranean littoral. Publ Espec Inst Esp Oceanogr 22:31-38

Editorial responsibility: Otto Kinne (Editor),

Oldendorf/Luhe, Germany
Sokal RR, Rohlf FJ (1981) Biometry, 2nd edn. WH Freeman and Company, New York, p 716-721

Stockner JG (1988) Phototrophic picoplankton: an overview from marine and freshwater ecosystems. Limnol Oceanogr $33(4): 765-775$

Stockner JG, Antia NJ (1986) Algal picoplankton from marine and freshwater ecosystems: a multidisciplinary perspective. Can J Fish Aquat Sci 43:2472-2503

Waterbury JB, Watson SW, Valois FW, Franks DG (1986) Biological and ecological characterization of the marine unicellular cyanobacterium Synechococcus. In: Platt T, Li WKW (eds) Photosynthetic picoplankton. Can Bull Fish Aquat Sci 214:71-120

Submitted: February 11, 1998; Accepted: July 1, 1998 Proofs received from author(s): August 6, 1998 